\title{
Communication
}

\section{Calmodulin-Like Fanction of Calcium-Binding Protein in Bovine Milk}

\author{
Masaaki TAMURA, Tsuneyuki OKU, and Norimasa Hosoy ${ }^{1}$ \\ Department of Nutrition, School of Health Sciences, \\ Faculty of Medicine, University of Tokyo, \\ Bunkyo-ku, Tokyo 113, Japan
}

(Received April 3, 1981)

Key Words calmodulin, calcium-binding protein, bovine milk, galactosyltransferase

A unique calcium-binding protein, calmodulin, has been shown to cause $\mathrm{Ca}^{2+}$. dependent activation of certain enzymes, and to localize in various tissues (1). The enzyme protein, such as phosphodiesterase, is activated by forming a complex with the calmodulin in the presence of $\mathrm{Ca}^{2+}(2)$. Calmodulin appears to be a key substance mediating the regulatory function of calcium ions in the cell.

In the previous paper(3), we reported that two different calcium binding proteins (mCaBP-3 and $\mathrm{mCaBP}-4)$ were found in bovine milk. The physicochemical properties of the two $\mathrm{CaBPs}$ closely resembled each other. Both CaBPs had two kinds of binding sites for $\mathrm{Ca}^{2+}\left(K_{\mathrm{d}} \fallingdotseq 1.7 \times 10^{-6} \mathrm{M}\right.$ and $\left.K_{\mathrm{d}} \fallingdotseq 5.1 \times 10^{-4} \mathrm{M}\right)$, were heatstable, and had a molecular weight of approximately 15,000. Further studies (4) confirmed the fact that $\mathrm{mCaBP}-3$ and $\mathrm{mCaBP}-4$ were a holoprotein and an apoprotein, respectively. These properties of milk $\mathrm{CaBPs}$ are very similar to those of calmodulin. Therefore, it seems that the milk $\mathrm{CaBP}$ has a calmodulin-like function such as the stimulation of enzyme activity. On the other hand, it was demonstrated that galactosyltransferase is involved in the synthesis of lactose in a mammary gland (5). The enzyme requires a small molecular protein, as well as the milk CaBP, and a divalent cation to display the maximal activity(6). Accordingly, it was initially studied whether or not milk CaBP could stimulate the activity of galactosyltransferase from bovine milk. In the present communication, we report on the $\mathrm{Ca}^{2+}$-dependent stimulation of galactosyltransferase in the presence of bovine milk CaBP.

UDP-[U- $\left.{ }^{14} \mathrm{C}\right]$ galactose (specific activity $274 \mathrm{mCi} / \mathrm{mmol}$ ), ${ }^{45} \mathrm{CaCl}_{2}$ (specific activity $21.4 \mathrm{mCi} / \mathrm{mgCa}$ ) and Omnifluor were purchased from New England Nuclear (Boston, MA). Galactosyltransferase from bovine milk and UDP-galactose

\footnotetext{
${ }^{1}$ 田村正明，奥 恒行，細谷憲政
} 


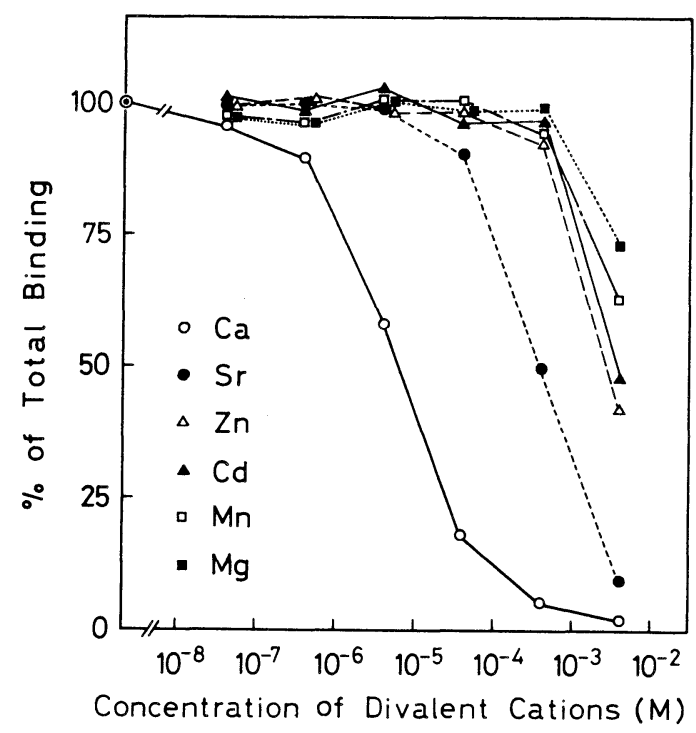

Fig. 1. Effect of various cations on the binding of ${ }^{45} \mathrm{Ca}$ to $\mathrm{mCaBP}-4$. Purified bovine mCaBP-4 $(250 \mu \mathrm{l}, 102 \mu \mathrm{g}$ protein/ml $)$ was incubated with $10 \mu \mathrm{l}$ of ${ }^{45} \mathrm{CaCl}_{2}$ $\left(3.8 \mu \mathrm{l}\right.$ of $\left.\mathrm{CaCl}_{2}, 35,000 \mathrm{cpm}\right)$ and $25 \mu \mathrm{l}$ of various divalent cations $(0.5 \mu \mathrm{M}$ to $50 \mathrm{~mm})$ at $25^{\circ} \mathrm{C}$ for $20 \mathrm{~min}$. Protein-bound ${ }^{45} \mathrm{Ca}$ was measured by the Chelex-100 procedure. Each point is the mean of duplicate determinations expressed as the percentage of total binding without any additive divalent cations $(\odot)$.

were from Sigma Chem. Co. (St. Louis, MO). Guanosine 5'-triphosphate (GTP) was from Wako Pure Chem. Indust. (Osaka). Chelex-100 chelating resin was from Bio-Rad Lab. (Richmond, CA). Dowex AG-1 (X2) was from Dow Chem. Co. (Midland, MI). Other chemicals were of analytical grade.

The milk CaBP was purified from unpasteurized bovine skim milk as previously described (3). The specificity of $\mathrm{CaBP}$ for several divalent cations was assessed by a competitive binding assay of Wasserman et al. (7) using 50\% Chelex100 resin suspension (i.e. Chelex-100 procedure). Galactosyltransferase activity was measured according to the incorporation method modified by Nagamatsu and Oka (8). The reaction was carried out at $37^{\circ} \mathrm{C}$ for $30 \mathrm{~min}$, and stopped with an equal volume of $20 \mathrm{~mm}$ EDTA, $\mathrm{pH}$ 7.4. The radioactivity that passed through a Dowex AG-1 (X2) column was collected and counted with a liquid scintillation counter. Protein concentration was determined by the method of Lowry et al.(9) using crystalline bovine serum albumin as a standard.

In order to assess the ligand specificity of milk CaBP, the purified CaBP was incubated with ${ }^{45} \mathrm{Ca}$ in the presence of various amounts of cations, and then the protein-bound ${ }^{45} \mathrm{Ca}$ was measured by Chelex-100 procedure. The relative affinity of milk CaBP was estimated by comparing the concentration of divalent cations required to reduce ${ }^{45} \mathrm{Ca}$ bound to the $\mathrm{CaBP}$. The results are shown in Fig. 1. Other 
Table 1. Stimulation of galactosyltransferase activity by milk CaBP in the presence of $\mathrm{Mn}^{2+}$ and $\mathrm{Ca}^{2+}$.

The reaction mixture consisted of the following: $50 \mu \mathrm{l}$ of $27 \mathrm{~mm}$ Tris- $\mathrm{HCl}$ buffer ( $\mathrm{pH} 7.4$ ) containing $44 \mathrm{~mm}$ glucose; $1.54 \mathrm{~mm}$ UDP-galactose supplemented with $30,000 \mathrm{cpm}$ of UDP- $\left[{ }^{14} \mathrm{C}\right]$ galactose and $1.1 \mathrm{~mm}$ GTP; $10 \mu$ lof bovine galactosyltransferase solution (1.0 unit $/ \mathrm{ml}$ ) in $20 \mathrm{~mm}$ Tris- $\mathrm{HCl}$ buffer containing $11 \mathrm{mM} \mathrm{MgCl}_{2}$ and $110 \mathrm{~mm} \mathrm{KCl}$ at $\mathrm{pH} 7.4$; $40 \mu \mathrm{l}$ of purified mCaBP-4 $(150 \mu \mathrm{g} / \mathrm{ml})$; and $20 \mu \mathrm{l}$ of various amounts of $\mathrm{CaCl}_{2}$ or $\mathrm{MnCl}_{2}$ as indicated (total volume $120 \mu \mathrm{l}$ ). See text for assay condition. Each value is expressed as the mean of duplicate determinations.

\begin{tabular}{cccc}
\hline \multirow{2}{*}{$\begin{array}{c}\mathrm{Ca}^{2+} \\
\text { concentration } \\
(\mathrm{M})\end{array}$} & Lactose produced $(\mathrm{nmol}) / 30 \mathrm{~min}$ \\
\cline { 2 - 4 } & none & $\mathrm{Mn}^{2+}$ concentration $(\mu \mathrm{M})$ & 2.8 \\
\hline none & 0.32 & 0.29 & 0.92 \\
$2.8 \times 10^{-6}$ & 0.31 & 0.36 & 1.18 \\
$2.8 \times 10^{-5}$ & 0.39 & 0.42 & 1.42 \\
$2.8 \times 10^{-4}$ & 0.40 & 0.47 & 3.06 \\
$2.8 \times 10^{-3}$ & 0.30 & 0.53 & 4.88 \\
$2.8 \times 10^{-2}$ & 0.30 & 0.65 & 1.85 \\
\hline
\end{tabular}

divalent cations than $\mathrm{Ca}^{2+}$ were significantly weaker competitors. The order of affinity for milk CaBP was as follows: $\mathrm{Ca}^{2+} \gg \mathrm{Sr}^{2+}>\mathrm{Zn}^{2+}>\mathrm{Cd}^{2+}>\mathrm{Mn}^{2+}>\mathrm{Mg}^{2+}$. The milk CaBP was specifically bound to $\mathrm{Ca}^{2+}$.

It is a generally recognized fact that galactosyltransferase is activated by $\mathrm{Mn}^{2+}$, forming a complex of $\mathrm{Mn}^{2+}$ and enzyme (10). When various amounts of $\mathrm{Mn}^{2+}$ were added to the reaction mixture in the presence of $\mathrm{mCaBP}-4$, galactosyltransferase activity was significantly stimulated at $28 \mu \mathrm{M}$ of $\mathrm{Mn}^{2+}$ concentration. But when $\mathrm{Ca}^{2+}$ was substituted for $\mathrm{Mn}^{2+}$ in the reaction mixture, the enzyme activity was not stimulated. A more detailed investigation by steady state kinetics with $\mathrm{Mn}^{2+}$ plus $\mathrm{Ca}^{2+}$ confirmed that the enzyme activity was further stimulated by the addition of $\mathrm{Ca}^{2+}$ in the presence of low concentrations of $\mathrm{Mn}^{2+}$ $\left(10^{-6}-10^{-5} \mathrm{M}\right)$ (Table 1$)$. The enzyme activity was maximal at $28 \mu \mathrm{M}$ of $\mathrm{Mn}^{2+}$ and $2.8 \mathrm{mM}$ of $\mathrm{Ca}^{2+}$ in the presence of mCaBP-4. But at $2.8 \mu \mathrm{M}$ of $\mathrm{Mn}^{2+}$, the enzyme could not display the maximal activity dependent on the increase of $\mathrm{Ca}^{2+}$ concentration. In the assay system without $\mathrm{mCaBP}-4$, the stimulation of enzyme activity failed to occur even in the presence of both $\mathrm{Ca}^{2+}$ and $\mathrm{Mn}^{2+}$. These results suggest that the maximum-activity of galactosyltransferase is achieved not only by $\mathrm{Mn}^{2+}$, but also by $\mathrm{Ca}^{2+}$ in the presence of $\mathrm{mCaBP}-4 . \mathrm{Mn}^{2+}$ concentration in bovine milk is approximately $0.7 \mu \mathrm{M}$ in the physiological state(11). In this concentration of $\mathrm{Mn}^{2+}$, galactosyltransferase cannot display the full activity. Therefore, $\mathrm{Ca}^{2+}$ seems to be essential for activation of galactosyltransferase in the physiological state. Milk CaBP performs a conformational change from mCaBP-4 to $\mathrm{mCaBP}-3$ in the presence of $\mathrm{Ca}^{2+}(4)$. The stimulation of the enzyme activity,

Vol. 27, No. 5, 1981 
however, did not differ between a holoprotein and an apoprotein of milk CaBP. The reason for this seemed to be that it was too low in the endogenous $\mathrm{Ca}^{2+}$ concentration to stimulate the enzyme activity. On the other hand, $\alpha$-lactalbumin is known to be one of the proteins concerning lactose synthesis(12), and its physicochemical properties, such as molecular weight and heat-stability, are very similar to milk CaBP. Therefore, milk CaBP may be an identical protein to $\alpha$ lactalbumin. However, it is not proven whether or not $\alpha$-lactalbumin specifically binds to $\mathrm{Ca}^{2+}$ and plays a regulatory function of galactosyltransferase activity by binding $\mathrm{Ca}^{2+}$.

From these results, it can be concluded that milk CaBP has a calmodulin-like function. However, further studies are required to determine if milk $\mathrm{CaBP}$ has a similar function for other enzymes which are stimulated by the established calmodulin of other tissues.

\section{REFERENCES}

1) Cheung, W. Y. (1980): Calmodulin plays a pivotal role in cellular regulation. Science, 207, 19-27.

2) Teshima, Y., and Kakiuchi, S. (1974): Mechanism of stimulation of $\mathrm{Ca}^{2+}$ plus $\mathrm{Mg}^{2+}$ dependent phosphodiesterase from rat cerebral cortex by the modulator protein and $\mathrm{Ca}^{2+}$. Biochem. Biophys. Res. Commun., 56, 489-495.

3) Tamura, M., Oku, T., and Sugiura, K. (1981): Purification and characterization of calcium-binding protein from bovine milk. Jpn. J. Vet. Sci., 43, 539-551.

4) Tamura, M., Oku, T., and Hosoya, N. (1981): Further characterization and physiological role of calcium-binding proteins from bovine milk. Proc. 91st Meet. Jpn. Soc. Vet. Sci., Tokyo, p. 36.

5) Watkins, W. M., and Hassid, W. Z. (1962): The synthesis of lactose by particulate enzyme preparations from guinea pig and bovine mammary glands. J. Biol. Chem., 237, $1432-1440$.

6) Brodbeck, U., and Ebner, K. E. (1966): Resolution of a soluble lactose synthetase into two protein components and solubilization of microsomal lactose synthetase. J. Biol. Chem., 241, 762-764.

7) Wasserman, R. H., Corradino, R. A., and Taylor, A. N. (1968): Vitamin D-dependent calcium-binding protein. Purification and some properties. J. Biol. Chem., 243, 3978-3986.

8) Nagamatsu, Y., and Oka, T. (1980): Purification and characterization of mouse $\alpha$ lactalbumin and preparation of its antibody. Biochem. J., 185, 227-237.

9) Lowry, O. H., Rosebrough, N. J., Farr, A. L., and Randall, R. J. (1951): Protein measurement with folin phenol reagent. J. Biol. Chem., 193, 265-275.

10) Khatra, B. S., Herries, D. G., and Brew, K. (1974): Some kinetic properties of human milk galactosyltransferase. Eur. J. Biochem., 44, 537-560.

11) Sato, M., and Murata, K. (1932): Manganese content of milk. J. Dairy Sci., 15, 461-467.

12) Brew, K., and Hill, R. L. (1975): Lactose biosynthesis. Rev. Physiol. Biochem. Pharmacol., 72, 105-158. 